\title{
Reproductive biology of the deep-sea holothurians Laetmogone violacea and Benthogone rosea (Elasipoda: Holothurioidea)
}

\author{
P. A. Tyler ${ }^{1}$, A. Muirhead ${ }^{1}$, D. S. M. Billett ${ }^{2} \&$ J. D. Gage ${ }^{3}$ \\ ${ }^{1}$ Department of Oceanography, University College, Singleton Park, Swansea SA2 8PP, United Kingdom \\ ${ }^{2}$ Institute of Oceanographic Sciences, Brook Road, Wormley, Godalming, Surrey, United Kingdom \\ ${ }^{3}$ Scottish Marine Biological Association. P. O. Box 3, Oban, Argyll, Scotland, United Kingdom
}

\begin{abstract}
Specimens were examined from a number of stations (960 to $2120 \mathrm{~m}$ depth) in the Porcupine Seabight and Rockall Trough, N. E. Atlantic Ocean. Both species are gonochoric and show an equal division of the sexes. The ovary of Laetmogone violacea is a compact nodose structure containing eggs up to $400 \mu \mathrm{m}$ diameter. The testis is highly digitate, with the wall of each tubule containing numerous infoldings lined with spermatogonia and spermatocytes; spermatozoa reach a maximum size of $2 \mu \mathrm{m}$ (head diameter). The ovary of Benthogone rosea consists of thin-walled nodose tubules through which the large egg of $750 \mu \mathrm{m}$ diameter can be clearly seen. The testis of $B$. rosea is a small digitate structure, the walls of which lack the infoldings found in L. violacea; spermatozoa have a head diameter of 5 to $7 \mu \mathrm{m}$. In neither species is there any evidence for reproductive seasonality.
\end{abstract}

\section{INTRODUCTION}

Holothurians comprise a large and conspicuous proportion of the total biomass of the benthic boundary at great depths (Pawson 1966, Filatova 1969, Menzies et al. 1973, Barnes et al. 1976, Khripounoff et al. 1980, Sibuet \& Lawrence 1981). They appear regularly in deep-sea photographs (Heezen \& Hollister 1971) and may be observed occurring singly or in large aggregations (Barham et al. 1967, Barnes et al. 1976, Billett \& Hansen 1982). Of the 6 orders of holothurians, the Elasipoda are the most common in the deep-sea. Although the taxonomy and zoogeography of this order have been described extensively by Hansen (1975), our knowledge of the reproductive biology of deep-sea holothurians remains rather limited. In general, shallow-water holothurians show a wide variety of reproductive habits (Hyman 1955) but only the commercially important species of shallow-water holothurians have received much attention (Tanaka 1958, Krishnaswamy \& Krishnan 1967, Krishnan 1968, Conand 1981). Elsewhere, especially along the seaboard of North America, studies of a limited number of brooding and indirectly developing species have been undertaken (Pearse 1968, Rutherford 1973, Green 1978, Engstrom 1980).
In accounts of the truly deep-sea species, reproduction has usually been given little more than cursory attention. Mortensen (1927) and Heding $(1935,1942)$ briefly discuss egg size in relation to development within deep-sea holothurians whilst Hansen (1975) devotes a section of his monograph on the Elasipoda to reproduction, although the number of specimens examined is small. More recently, Billett \& Hansen (1982) described the egg size of the elasipod Kolga hyalina as $180 \mu \mathrm{m}$ diameter and predicted lecithotrophic development, whilst for the dendrochirote Ypsilothuria bitentaculata (mistakenly given as $Y$. talismani; see Gage et al. 1985), Tyler \& Gage (1983) described a maximum fecundity of $<50$ eggs individual $^{-1}$ with the eggs growing to a maximum size of $350 \mu \mathrm{m}$. This was thought to suggest lecithotrophic development, with a reduced larval stage for this species.

Laetmogone violacea is considered to be a typically bathyal species with almost a cosmopolitan distribution that may be dependent on ocean currents (Hansen 1975). It has a general depth range of 225 to $1804 \mathrm{~m}$ (Hansen 1975) but in the Rockall Trough and Porcupine Seabight, it is found at depths of 700 to $1500 \mathrm{~m}$. Benthogone rosea appears to have a widespread distribution in the E. Atlantic, S. W. Pacific and W. Indian 

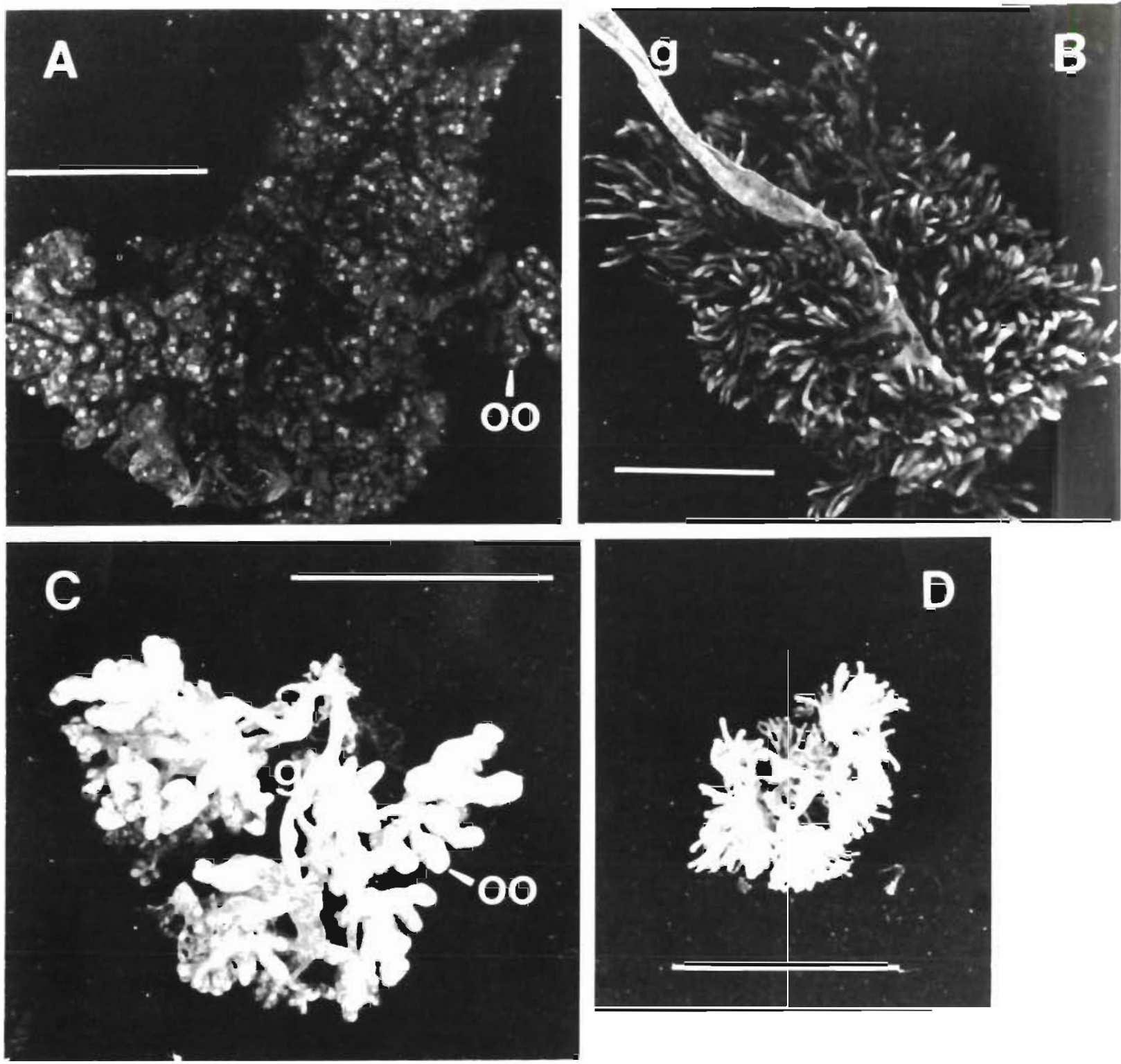

Fig. 1. Gross morphology of gonads. (A) Laetmogone violacea, ovary, (B) testis. (C) Benthogone rosea, ovary, (D) testis. g: gonoduct; oo: oocyte. Bar: $10 \mathrm{~mm}$

develops it is surrounded by follicle cells which are believed to act as nutritive support cells for the developing oocyte. Rarely were oocytes observed to be undergoing phagocytosis.

Histologically the gonoduct consists of the epithelial linings of the ovary wall but these are separated by a very thick connective tissue layer and two layers of muscle.

To determine the oocyte size distribution in each specimen, and to determine any variation between samples, oocyte size-frequency figures have been constructed. Examination of individual specimen oocyte size-frequencies suggests that there is a pool of immature oocytes $<150 \mu \mathrm{m}$ which numerically constitute the vast majority of oocytes present and that some of these develop, undergo vitellogenesis and grow to a maximum size of ca $350 \mu \mathrm{m}$ diameter before being spawned. There is some suggestion that these vitellogenic oocytes develop as a distinct cohort, whilst in other specimens there is a steady production of vitellogenic oocytes.

Within the sample-summated oocyte size-frequency figure (Fig. 3) there is no evidence of any reproductive seasonality although no winter or early spring samples have been collected. These data have been analysed by an $\mathrm{I} \times \mathrm{k}$ contingency table and the null hypothesis that there is no difference between the 9 samples is accepted $\left(\chi^{2}=90.55, \mathrm{df}=96, p=<0.001\right)$. 

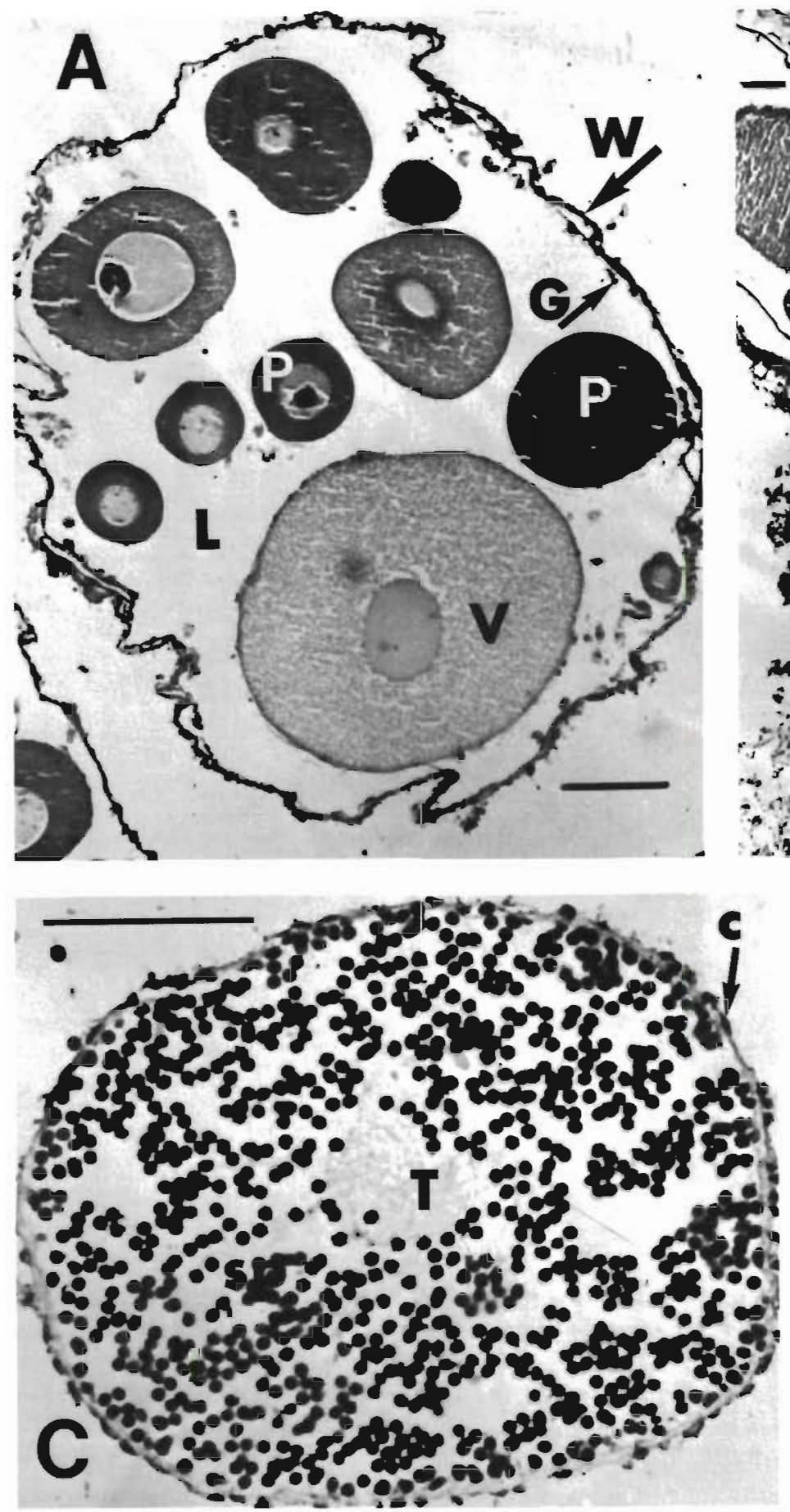
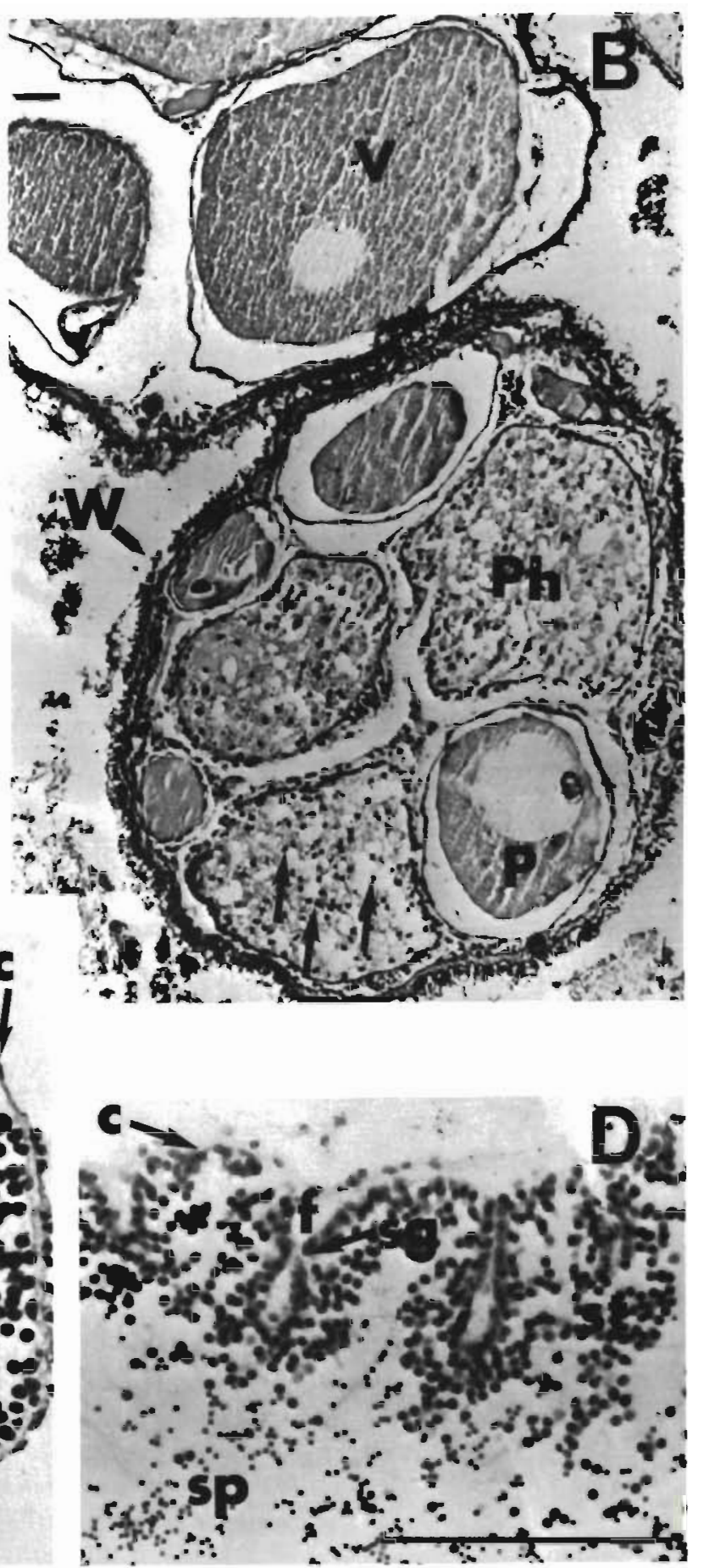

Fig. 2. (A) Laetmogone violacea, oogenesis; (B) Benthogone rosea, oogenesis; (C) B. rosea, spermatogenesis; (D) L. violacea spermatogenesis. W: gonad wall; P: previtellogenic oocyte; V: vitellogenic oocyte; L: lumen of gonad; G: germinal epithelium, Ph: phagocytosed oocyte; $\Rightarrow$ : individual phagocytes in (B); sp: spermatozoa; $\mathrm{T}$ : sperm tails; c: coelomic epithelium; sg: spermatogonia; f: fold in germinal epithelium. Horizontal bars: $100 \mu \mathrm{m}$. All haemalum and eosin except (A) (Toluidine blue)

Microscopic and oocyte size-frequency observations of gametogenesis in Benthogone rosea

The wall structure of Benthogone rosea is similar to that of Laetmogone violacea except that there is a much greater cellular presence in $B$. rosea than in $L$ violacea. The original clumps found in $L$. violacea are not as easy to identify in $B$. rosea. However, subcellular previtellogenic oocyte growth appears to follow a similar pattern although oocytes in this stage in 


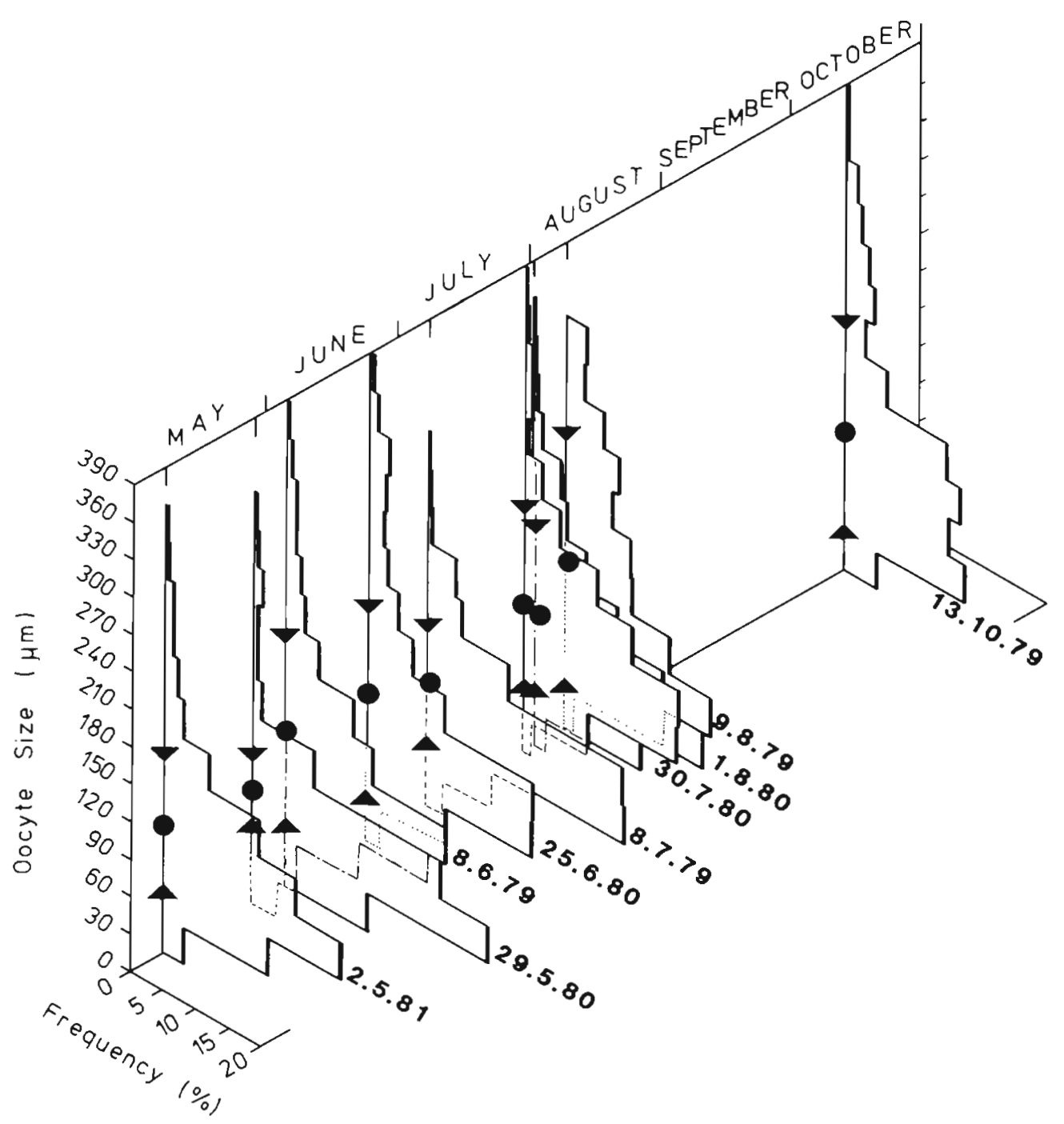

Fig. 3. Laetmogone violacea. Summated sample oocyte size-frequency of all seasonal samples. Samples from different years are plotted on an annual axis; $\bullet$ mean oocyte size; $\Delta \pm 1$ standard deviation

B. rosea are surrounded by numerous follicle cells (Fig. 2B). Vitellogenesis appears to commence at an oocyte diameter of about $300 \mu \mathrm{m}$. At this stage, fine PASpositive granules appear and the oocyte then grows to a maximum size of $750 \mu \mathrm{m}$. There is some evidence from sections through the tips of the gonad tubules that previtellogenic activity is highest at these distal points. In the largest oocytes (ca $700 \mu \mathrm{m}$ ) the cytoplasm contains dense granular PAS-positive material and in some oocytes a 'dent' in the nucleus appears to open to the oocyte surface. The nucleolus is also very eccentric within the nucleus.

Some oocytes, particularly in the range 200 to 300 $\mu \mathrm{m}$ diameter were permeated with follicle cells suggesting some form of phagocytic process. The follicle cells that had supported the early growth of the oocyte now invade the oocyte and result in its complete breakdown (Fig. 2B). The proportion of oocytes $>200$ $\mu \mathrm{m}$ being broken down varied from zero in newly developed specimens to ca $40 \%$ in well developed specimens. This 'nurse cell' pattern has been observed in a number of deep sea asteroids (Tyler et al. 1982a, Pain 1983).

On capture, a large number of Benthogone rosea were found to have eviscerated. In many cases only a few gonadial strands could be found, just enough to determine the sex. In the remaining cases oocyte sizefrequency analyses were attempted, but we believe that partial spawning of many of the specimens had taken place during capture. However, we present oocyte size-frequency counts for 7 intact specimens (Fig. 4). These data suggest there is a 'pool' of previtellogenic oocytes $<250 \mu \mathrm{m}$ diameter and that from this pool a limited number of oocytes undergo vitel- 
logenesis, possibly supported by phagocytosed oocytes, to reach the maximum oocyte size of $750 \mu \mathrm{m}$ at which point they are spawned. The paucity of large oocytes in these figures suggests some release of gametes took place during capture. This pattern is typical of deep-sea asteroids with direct development (Tyler et al. 1983)

\section{Spermatogenesis in Laetmogone violacea and Benthogone rosea}

The germinal epithelium of the testis of Laetmogone shows numerous infoldings (Fig. 2D) that are lined with spermatogonia (ca $70 \mu \mathrm{m}$ diameter). These divide to give a thin layer of spermatocytes which then undergo reduction division to produce spermatids that mature into round-headed spermatozoa (2.0 $\mu \mathrm{m}$ diameter). The testis appeared to be in a continually mature condition ready for spawning on meeting a female.

The germinal epithelium of the testis of Benthogone rosea rarely showed the infolding found in Laetmogone violacea except in some narrow distal tubules.
The gonads usually contained loosely packed spermatozoa (Fig. 2C) with very little evidence of other spermatogonial cells. The heads of these spermatozoa were large (ca 5 to $7 \mu \mathrm{m}$ diameter) and round, whilst the sperm tail extended into the lumen of the testis.

\section{DISCUSSION}

It is of considerable interest that these 2 closely related elasipod holothurians show interspecific variability in their reproductive pattern. Both are widespread species with Laetmogone violacea being found on the upper to mid-continental slope, whilst Benthogone rosea is found on the middle and lower slope. All the specimens we have examined are mature, although at least $50 \%$ of specimens of $B$. rosea had totally eviscerated during capture. Hansen (1975) suggests that $L$. violacea reaches reproductive maturity at $50 \mathrm{~mm}$ length whilst the smallest specimen of $B$. rosea examined (ca $44 \mathrm{~mm}$ ) was already undergoing development.

The pattern of early oogenesis, with oogonia giving

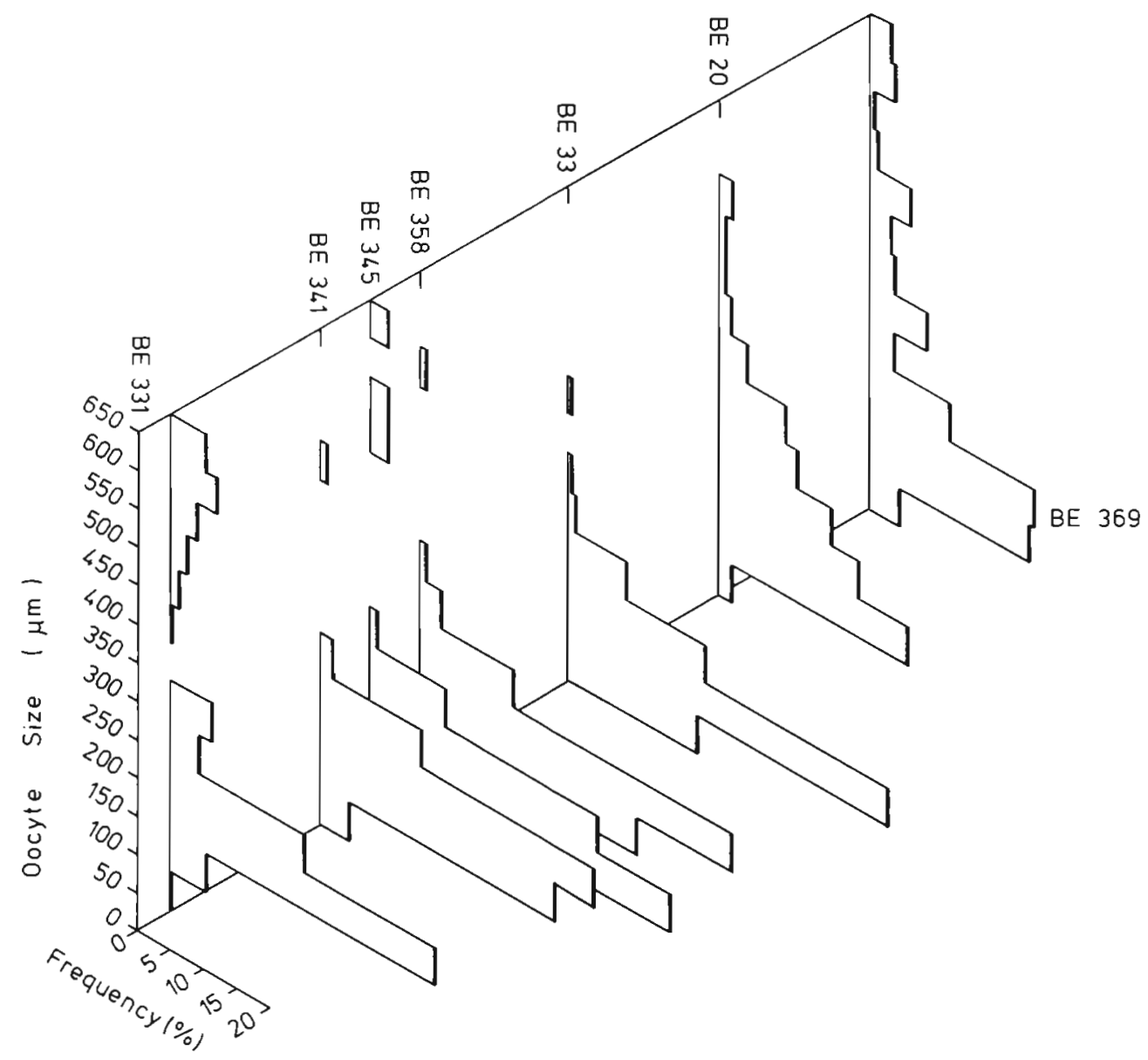

Fig. 4. Benthogone rosea. Oocyte size-frequency values of individuals that had not eviscerated on capture 
rise to previtellogenic oocytes, would appear to be similar in both species. In Laetmogone violacea these oocytes begin yolk production at about $150 \mu \mathrm{m}$ before increasing in size to a maximum of $350 \mu \mathrm{m}$ diameter. However, the oocytes of Benthogone rosea remain previtellogenic until about $300 \mu \mathrm{m}$ diameter before undergoing yolk production to produce eggs in excess of 750 $\mu \mathrm{m}$ diameter. In both species the germinal vesicle was intact, even in the largest oocytes, suggesting that reduction division takes place immediately before spawning, or in the water column after spawning. In $L$. violacea nearly all the oocytes were spawned whereas in $B$. rosea a number of oocytes in the size range 200 to $300 \mu \mathrm{m}$ underwent phagocytic breakdown. During egg production follicle cell activity appeared to be much greater in $B$. rosea than in $L$. violacea.

From these data we can make certain inferences. The egg size of Laetmogone violacea is considered an 'intermediate' egg size between the small eggs of planktotrophic developers $(<100 \mu \mathrm{m})$ and the large eggs $(>600 \mu \mathrm{m})$ of direct developers. This intermediate egg size has been found in only 2 other deep-sea echinoderms, both typically slope species, the large epifaunal brittle star Ophiomusium lymani and the small, deposit-feeding dactylochirote Ypsilothuria bitentaculata (Gage \& Tyler 1982, Tyler \& Gage 1983, as $Y$. talismani). By comparison with shallow-water species (Hendler 1979), it is suggested that this size of egg gives rise to an 'abbreviated' larva.

Although no direct evidence is available we may expect these abbreviated larvae to be dispersed throughout the adult population by near-bed current activity.

As with other echinoderm species producing an egg of the intermediate size, spawning is a complete process in Laetmogone violacea. Maximally developed oocytes are rarely found undergoing follicle cell activity, thus negating the need for any recycling processes. In contrast, Benthogone rosea produces the large egg typical of direct development to a juvenile usually considered to occur close to the adult population. It would appear that large eggs are more difficult to maintain in the ovary and if not spawned are phagocytosed by follicle cell activity so that the energy is retained within the adult rather than being lost to the environment. This dichotomy of follicle cell activity between those species producing intermediate and large eggs is a common feature amongst oogenesis in deep sea echinoderms.

From the available data there was no evidence of reproductive synchrony related to any of the seasonal phenomena that have been recently identified from the deep-sea (Deuser \& Ross 1980, Deuser et al. 1981, Dickson et al. 1982, Tyler et al. 1982, Billett et al. 1983).
The reproductive pattern observed in Laetmogone violacea and Benthogone rosea would appear to be more typical of deep sea echinoderms as 30 out of 36 species so far examined appear to reproduce year round.

Within the males the spermatogenic process was not distinctly different between the species. The germinal epithelium of the testes of Laetmogone violacea was in folds which increases the surface area of spermatogenesis. The much larger sperm head (ca $7 \mu \mathrm{m}$ ) of Benthogone rosea, compared to that of L. violacea (ca 2 to $3 \mu \mathrm{m}$ ) may be related to the need to penetrate the larger egg of $B$. rosea.

These data pose a number of questions. First, the rate of vitellogenesis and egg production in each species remains unknown; it may take weeks, or years. After feeding we do not know how long storage lasts; nutrients may be stored in the body wall in holothurians or transported directly to the gonads. The lateral or vertical transport of large eggs is not usually expected, but an abbreviated larva may be transported up, down or along the slope perhaps for considerable distances.

Acknowledgements. We thank Professor F. T. Banner in whose department the work was carried out; the Master und Crew of R. R. S. 'Challenger' for their assistance at sea. The Scottish Marine Biological Association is Grant-aided by the Natural Environment Research Council. This research was carried out under contract from the Department of the Environment as part of its radioactive waste management research programme. While the results may be used in the formulation of Government policy, at this stage they do not necessarily represent Government policy.

\section{LITERATURE CITED}

Aldred, R. G., Thurston, M. H., Rice, A. L., Morley, D. R. (1976). An acoustically monitored opening and closing epibenthic sledge. Deep Sea Res. 23: 167-174

Barham, E. G., Ayer, N. J., Boyce, R. E. (1967). Macrobenthos of the San Diego Trough; photographic census and observations from bathyscaphe Trieste. Deep Sea Res. 14: $773-784$

Barnes, A. T., Quetin, L. B., Childress, J. J., Pawson, D. L., (1976). Deep-sea macroplanktonic sea cucumbers: suspended sediment feeders captured from deep submergence vehicle. Science 194: 1083-1085

Billett, D. S. M., Hansen, B. (1982). Abyssal aggregations of Kolga hyalina D \& K (Echinodermata: Holothurioidea) in the N. E. Atlantic Ocean: a preliminary report. Deep Sea Res. 29: 799-818

Billett, D. S. M., Lampitt, R. S., Rice, A. L., Mantoura, R. F. C. (1983). Seasonal sedimentation of phytoplankton to the deep-sea benthos. Nature, Lond. 302: 502-522

Conand, C. (1981). Sexual cycle of three commercially important holothurian species (Echinodermata) from the lagoon of New Caledonian. Bull. mar. Sci. 31: 523-543

Deuser, W. G., Ross, E. H. (1980). Seasonal change in the flux of organic carbon to the deep Sargasso Sea. Nature, Lond. 283: $364-365$

Deuser, W. G., Ross, E. H., Anderson, R. F. (1981). Seasonality 
in the supply of sediment to the deep Sargasso Sea and its implications for the rapid transfer of matter to the deep ocean. Deep Sea Res. 28: 495-505

Dickson, R. R., Gould, W. J., Gurbutt, P. A., Killworth, P. D. (1982). A seasonal signal in ocean currents at abyssal depths. Nature, Lond. 295: 193-198

Engstrom, N. A. (1980). Reproductive cycles of Holothuria (Halodeima) floridana, H. (H.) mexicana and their hybrids (Echinodermata: Holothuroidea) in southern Florida, USA. Int. J. Invert. Rep. 2: 237-244

Filatova, Z. A. (1969). The quantitative distribution of the deep-sea bottom fauna. In: Kort, V. G. (ed.) The Pacific Ocean, Vol. 7. Biology of the Pacific Ocean, Book 2, The deep bottom fauna. Nauka Moskow, p. 202-216

Gage, J. D., Tyler, P. A. (1981). Growth and reproduction in the deep-sea brittlestar Ophiomusium lymani Wyville Thomson. Oceanologica Acta 5: 73-83

Gage, J. D., Billett, D. S. M., Jensen, M., Tyler, P. A. (1985). Echinoderms of the Rockall Trough. II. Echinoidea and Holothurioidea. Bull. Br. Mus. nat. Hist. (in press)

Grant, A., Tyler, P. A. (1983). The analysis of data in studies of invertebrate reproduction. I. Introduction and statistical analysis of gonad indices and maturity indices. Int. J. Invert. Rep. 6: 259-269

Green, J. D. (1978). The annual reproductive cycle of an apodous holothurian Leptosynapta tenuis: a biomodal breeding season. Biol. Bull. mar. biol. Lab., Woods Hole 154: $68-78$

Hansen, B. (1975). Systematics and biology of the deep-sea holothurians. I. Elasipoda. Galathea Rep. 13: 1-262

Heding, S. G. (1935). Holothurioidea. Part. I. Apoda-Molpadioidea-Gephyrothurioidea. Danish-Ingolf Expedition 4 (9): $1-84$

Heding, S. G. (1942). Holothurioidea. Part. II. AspidochirotaElasipoda-Dendrochirota. Danish-Ingolf Expedition 4 (13): $1-39$

Heezen, B. C., Hollister, C. D. (1971). The face of the deep. Oxford University Press, New York

Hendler, G. (1979). Reproductive periodicity of Ophiuroids (Echinodermata: Ophiuroidea) on the Atlantic and Pacific coasts of Panama. In: Stancyk, S. E. (ed.) Reproductive ecology of marine invertebrates. Univ. of S. Carolina Press, Columbia, p. 145-156

Hessler, R. R., Sanders, H. L. (1967). Faunal diversity in the deep sea. Deep Sea Res. 14: 65-78

Hyman, L. (1955). The invertebrates. IV. Echinodermata. McGraw Hill Book Co., New York

Khripounoff, A., Desbruyères, D., Chardy, P. (1980). Les peu- plements benthiques de la faille Vema: données quantitatives et bilan d'énergie en milieu abyssal. Oceanologica Acta 3: $187-198$

Krishnan, S. (1968). Histochemical studies on reproductive and nutritional cycles of the holothurian Holothuria scabra. Mar. Biol. 2: 54-65

Krishnaswamy, S., Krishnan, S. (1967). A report on the reproductive cycle of the holothurian Holothuria scabra. Curr. Sci. 36: 155-156

Menzies, R. J., George, R. Y., Rowe, G. T. (1973). Abyssal environment and ecology of the world oceans. Wiley \& Sons, London

Mortensen, T. (1927). Handbook of the echinoderms of the British Isles. Oxford University Press, London

Pain, S. L. (1983). Aspects of gametogenesis in deep-sea Asteroidea from the Rockall Trough, N. E. Atlantic. Ph. D. thesis, University of Wales

Pawson, D. L. (1966). Ecology of Holothurians. In: Boolootian, R. A. (ed.) Physiology of Echinodermata, Interscience Pub., New York, p. 63-71

Pearse, J. S. (1968). Patterns of reproductive periodicities in four species of Indo-Pacific Echinoderms. Proc. Indian Acad. Sci. (B) 67: 247-279

Rutherford, J. C. (1973). Reproduction, growth and mortality of the holothurian Cucumaria pseudocurata. Mar. Biol. 22: $167-176$

Sibuet, M., Lawrence, J. M. (1981). Organic content and biomass of abyssal holothuroids (Echinodermata) from the Bay of Biscay. Mar. Biol. 65: 143-147

Tanaka, Y. (1958). Seasonal changes in the gonad of Stichopus japonicus. Bull. Fac. Fish. Hokkaido Univ. 9: 29-36

Tyler, P. A., Grant, A., Pain, S. L., Gage, J. D. (1982a). Is annual reproduction in deep-sea echinoderms a response to variability in their environment? Nature, Lond. 300: $747-750$

Tyler, P. A., Pain, S. L., Gage, J. D. (1982b). The reproductive biology of the deep-sea asteroid Bathybiaster vexillifer. J. mar biol. Ass. U. K. 62: 57-69

Tyler, P. A., Gage, J. D. (1983). The reproductive biology of Ypsilothuria talismani (Holothuroidea: Dendrochirota) from the N. E. Atlantic. J. mar. biol. Ass. U. K. 63: 609-616

Tyler, P. A., Pain, S. L., Gage, J. D. (1983). Garnetogenic cycles in deep-sea phanerozoan asteroids from the N. E. Atlantic. In: Lawrence, J. M. (ed.) International Echinoderm Conferences, Tampa Bay. A. A. Balkema, Rotterdam, p. 431-434 